\title{
JURNAL BELAJAR SEBAGAI SARANA PENGEMBANGAN KEMAMPUAN METAKOGNISI SISWA
}

\author{
Nova Fitriani Wahdah ${ }^{1}$, A Wahab Jufri ${ }^{2}$, Lalu Zulkifli \\ ${ }^{1)}$ Mahasiswa Pendidikan Biologi, Jurusan PMIPA, FKIP Universitas Mataram \\ ${ }^{2}$ Dosen Pendidikan Biologi, Jurusan PMIPA, FKIP Universitas Mataram \\ Email: novafitrianiwahdah@gmail.com
}

\begin{abstract}
Abstrak. Penelitian ini bertujuan untuk menganalisis: (1) peningkatan kemampuan menulis jurnal belajar, (2) perbedaan kemampuan metakognisi siswa yang menulis jurnal belajar dengan siswa yang tidak menulis jurnal belajar, dan (3) hubungan kemampuan menulis jurnal belajar dengan kemampuan metakognisi siswa. Desain penelitian ini menggunakan nonequivalent control group design. Populasi dalam penelitian ini yaitu siswa kelas X dan kelas XI di SMAN 1 Pringgarata tahun ajaran 2014/2015 (285 orang). Sampel penelitian ditentukan melalui teknik simple random sampling. Sampel penelitian yang berjumlah 124 orang tersebar di kelas $\mathrm{X}_{3}$ dan $\mathrm{XI}$ $\mathrm{IPA}_{1}$ sebagai kelompok eksperimen, serta di kelas $\mathrm{X}_{2}$ dan XI IPA $\mathrm{A}_{2}$ sebagai kelompok kontrol. Instrumen penelitian berupa jurnal belajar, rubrik penilaian jurnal belajar, dan inventori kesadaran metakognisi. Data hasil penelitian dianalisis menggunakan program SPSS for windows 16. Hasil penelitian ini menunjukkan bahwa: (1) kemampuan siswa dalam menulis jurnal belajar mengalami peningkatan $(\mathrm{N}$-gain= 0,2), (2) ada perbedaan kemampuan metakognisi antara siswa yang menulis jurnal belajar dengan siswa yang tidak menulis jurnal belajar $(p<0,05)$, dan (3) kemampuan menulis jurnal belajar berkorelasi positif dengan kemampuan metakognisi $(p<$ $0,05)$.
\end{abstract}

Kata kunci: jurnal belajar, kemampuan metakognisi

\begin{abstract}
The aim of this research were to analyze: (1) the improvement of students ability in journal writing skills, (2) the difference of metacognitive skills between students who wrote learning journal and those who did not write learning journal, (3) the correlation of journal writing skills and the metacognitive skills of students. The research design was used nonequivalent control group design. The Population of this research were students in X and XI class of SMAN 1 Pringgarata 2014/2015 (285 peoples). Sample of this research was determined by simple random sampling technique. The amount of sample were 124 peoples, that distributed in $\mathrm{X}_{3}$ and $\mathrm{XI}_{\mathrm{IPA}}$ class as experimental group, $\mathrm{X}_{2}$ and $\mathrm{XI} \mathrm{IPA}_{2}$ class as control group. The research instruments were learning journal, rubric of learning journal and metacognitive awareness inventory (MAI). Data in this research was analyzed by using SPSS for windows 16. The result of this research shows: (1) the students skills in writing journal was increase $(\mathrm{N}$-gain $=0,2),(2)$ there were significant difference between students who wrote journal and those who did not write journal $(p<0,05)$, and (3) journal writing skills was positively correlated with the students metacognitive skill $(p<0,05)$.
\end{abstract}

Keywords: learning journal, metacognitive skills

\section{PENDAHULUAN}

Biologi di Sekolah Menengah Atas (SMA) merupakan salah satu mata pelajaran yang memiliki fungsi dan peran strategis dalam mendukung tercapainya tujuan pendidikan nasional. Adapun tujuan mata pelajaran biologi yang tercantum dalam Permendiknas Nomor 22 tahun 2006 [1] tentang Standar Isi adalah: Memupuk sikap ilmiah yaitu jujur, objektif, terbuka, ulet, kritis dan dapat bekerjasama dengan orang lain; mengembangkan kemampuan berpikir analitis, induktif, dan deduktif dengan menggunakan konsep dan prinsip biologi; menerapkan konsep dan prinsip biologi untuk menghasilkan karya teknologi sederhana yang berkaitan dengan kebutuhan manusia. Tujuan mata pelajaran biologi ini mengharapkan siswa dapat memberdayakan kemampuan berpikir kritisnya melalui pembelajaran biologi. Desmita [2] mengutip pendapat Seifert dan Hoffnung yang menyebutkan salah satu komponen kemampuan berpikir kritis adalah kemampuan metakognisi. Menurut Simamora [3] salah satu cara untuk mengembangkan kemampuan berpikir kritis siswa adalah dengan metakognisi.

Kemampuan metakognisi merupakan suatu proses berpikir tingkat tinggi untuk membangun strategi dalam memecahkan masalah, mengamati tingkat kemampuan kognitif dan memanfaatkan informasi dengan sebaik-baiknya untuk mencapai tujuan tertentu. Siswa pada tingkat SMA dituntut untuk memiliki kemampuan berpikir reflektif, kritis dan analitis, yang banyak memberdayakan kemampuan metakognisi. Kemampuan tersebut diyakini mampu membantu siswa untuk mengambil keputusan yang tepat, cermat, sistematis, logis dan mempertimbangkan berbagai sudut pandang $[4,5]$.

Kenyataan kurangnya perhatian terhadap kemampuan metakognisi pada siswa terjadi di SMAN 1 Pringgarata. Guru belum memberikan perhatian yang optimal pada kemampuan metakognisi siswa seperti mengevaluasi kelebihan dan kekurangan dalam belajar, manfaat mempelajari suatu materi pelajaran, dan menyusun strategi belajar. Kemampuan yang difokuskan hanya terbatas pada 
kemampuan kognisi siswa, misalnya hanya menghafal pengertian dari sebuah istilah yang baru dikenal oleh siswa.

Kegiatan refleksi diri merupakan salah satu cara untuk mengembangkan kemampuan metakognisi siswa. Graham [6] mengutip hasil penelitian Feathers dan White yang menyatakan bahwa jurnal belajar dapat meningkatkan kemampuan metakognisi siswa. Menurut Coughlan [7] refleksi akan membantu siswa fokus dan aktif berpartisipasi dalam perkembangannya sebagai seorang pembelajar efektif yang bebas dan kritis. Jurnal akan menjadi sebuah rekaman untuk kemajuan siswa secara keseluruhan dan akan membantu siswa menemukan strategi dan proses yang bekerja dengan baik bagi siswa. Refleksi merupakan cara tersendiri dalam belajar dan membantu siswa untuk mengevaluasi prestasi siswa sebagai pembelajar. Dengan melibatkan diri dalam refleksi belajar siswa berperan aktif dalam proses belajar dan mengenal tanggung jawabnya sebagai pembelajar sepanjang hayat.

Berdasarkan uraian di atas, maka perlu dilakukan penelitian yang bertujuan untuk mengetahui peningkatan kemampuan siswa dalam menulis jurnal belajar, mengetahui perbedaan kemampuan metakognisi kelas yang ditugaskan menulis jurnal belajar dengan kelas yang tidak ditugaskan menulis jurnal belajar, serta untuk mengetahui hubungan antar kemampuan menulis jurnal belajar dengan kemampuan metakognisi siswa di SMAN 1 Pringgarata. random sampling berjumlah 124 orang tersebar di kelas $\mathrm{X}_{3}, \mathrm{X}_{2}, \mathrm{XI} \mathrm{IPA}_{1}$ dan XI IPA 2 .

Rancangan penelitian yang digunakan adalah nonequivalent control group design. Kelompok data kemampuan menulis jurnal belajar diperoleh melalui penugasan menulis jurnal belajar. Kelompok data kemampuan metakognisi yang didapatkan melalui pengisian inventori kesadaran metakognisi yang diadopsi dari Metacognitive Awareness Inventory (MAI) milik Schraw dan Dennison (1994).

Analisis data dilakukan dengan tahapan uji normalitas, uji homogenitas dan uji hipotesis. Analisis data untuk menjawab hipotesis tentang perbedaan kemampuan metakognisi kelompok eksperimen dan kontrol adalah uji Mann-Whitney. Analisis data untuk menguji hipotesis tentang hubungan kemampuan menulis jurnal belajar dengan kemampuan metakognisi adalah uji korelasi.

\section{HASIL DAN PEMBAHASAN}

\section{Kemampuan Menulis Jurnal Belajar}

Jurnal belajar sebagai strategi berpikir metakognitif merupakan catatan hasil refleksi siswa pada setiap akhir proses pembelajaran dengan mengembangkan strategi berpikir metakognitif [5]. Skor kemampuan menulis jurnal belajar semakin lama semakin meningkat. Peningkatan ini menunjukkan adanya kemajuan-kemajuan yang telah dicapai siswa dalam menulis jurnal belajar. Kemajuan yang telah dicapai siswa selama penulisan jurnal belajar biologi 1 hingga 3 antara lain: strategi belajar yang digunakan mulai bervariasi, kegiatan berpikir

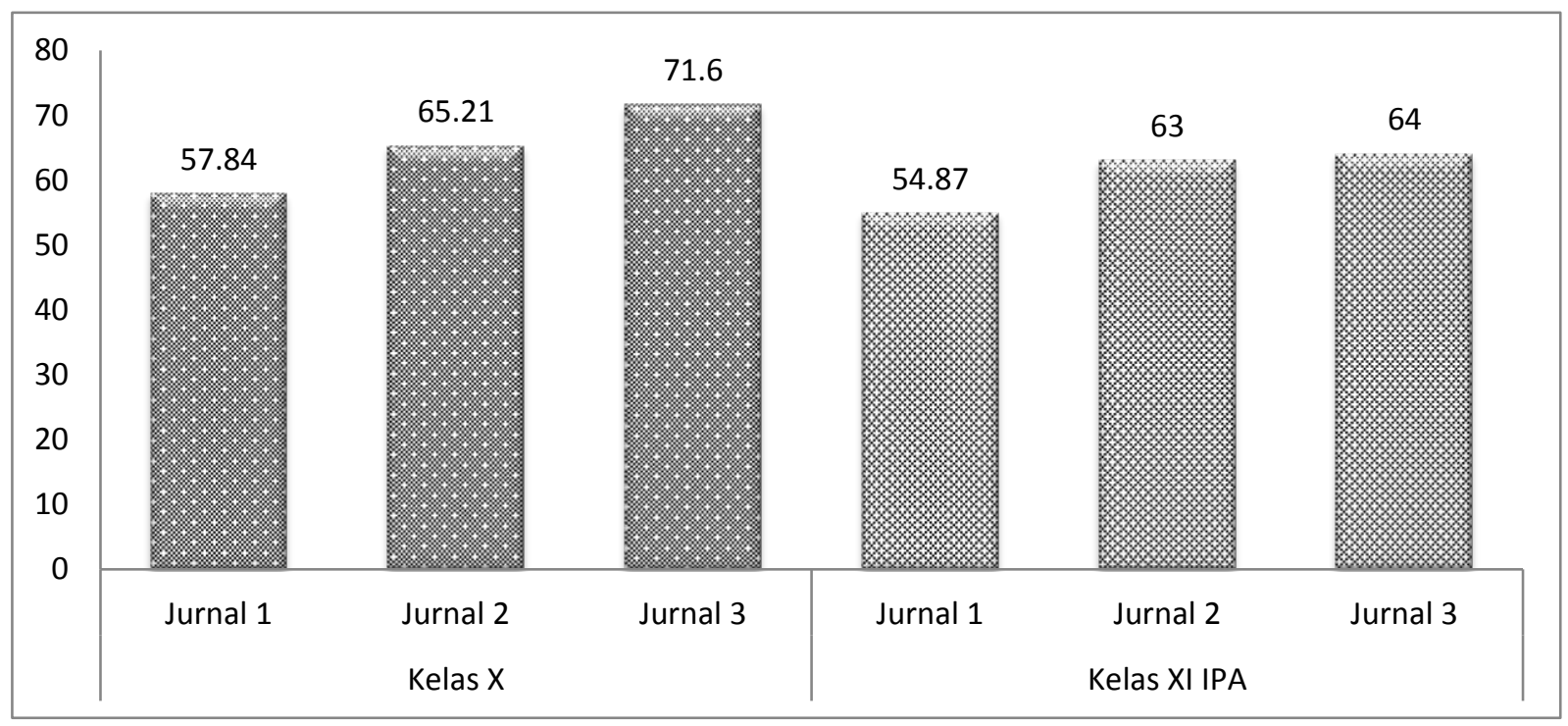

Gambar 1. Diagram Skor Rata-rata Jurnal 1, Jurnal 2 dan Jurnal 3

\section{METODE PENELITIAN}

Penelitian ini dilaksanakan di SMAN 1 Pringgarata tahun ajaran 2014/2015. Populasi pada penelitian adalah siswa kelas X dan kelas XI. Sampel penelitian yang didapatkan dengan teknik simple mendalam sudah mulai dilakukan walaupun belum sempurna, siswa lebih memahami kesulitan yang dialami, siswa sudah mulai mencari solusi untuk menyelesaikan kesulitan tersebut. Rata-rata skor kemampuan menulis jurnal belajar siswa ditunjukkan oleh Gambar 1. 
Penugasan menulis jurnal belajar dalam penelitian ini tidak hanya untuk mengembangkan kemampuan akademis, melainkan dapat memberikan motivasi kepada siswa untuk mengembangkan kemampuan non akademis. Seperti yang dikatakan oleh Laurens [8] dan Septiyana dkk. [5] diharapkan melalui kebiasaan menuliskan pengalaman belajar, siswa akan terbiasa mengekspresikan perasaaan, pemikiran atau harapannya tentang pembelajaran yang diberikan guru, serta mampu melihat kelebihan dan kelemahan dalam belajar.

Hasil penelitian ini menunjukkan ada peningkatan kemampuan menulis jurnal belajar biologi. Peningkatan ini dapat dilihat dari adanya peningkatan skor ternormalisasi (N-Gain) ratarata jurnal 1, 2 dan 3. Menurut Hake [9] apabila skor $\mathrm{N}$-Gain lebih dari 0,7 maka peningkatannya termasuk dalam kategori tinggi, sedangkan apabila skor N-Gain kurang dari 0,7 atau lebih dari 0,3 maka peningkatannya tergolong sedang, dan apabila skor N-Gain kurang dari 0,3 maka peningkatannya tergolong rendah. Skor (N-gain) rata-rata peningkatan kemampuan menulis jurnal belajar siswa yakni 0,2 yang masih tergolong dalam kategori rendah. Frekuensi kemampuan menulis jurnal belajar siswa kelas X yakni $97,36 \%$ masih tergolong rendah, dan 2,63\% tergolong sedang. Pada kelas XI 79,16\% kemampuan menulis jurnal belajar siswa masih tergolong rendah, dan 20,83\% tergolong sedang.

Peningkatan kemampuan menulis jurnal belajar ini didukung oleh 3 hukum pokok dalam proses belajar manusia menurut Thorndike dalam Jufri [10] yakni hukum kesiapan, hukum akibat dan hukum latihan. Menurut hukum kesiapan, hubungan antara stimulus dan respon mudah terbentuk kalau ada kesiapan pada diri seseorang. Hukum yang kedua yakni hukum akibat, suatu tindakan yang diikuti dengan akibat yang menyenangkan akan cenderung diulang-ulang. Hukum yang ketiga ialah hukum latihan, yang menyatakan bahwa hubungan antara stimulus dan respon akan menjadi lebih kuat karena adanya latihan

\section{Kemampuan Metakognisi}

Hasil uji hipotesis dalam penelitian ini menunjukkan ada perbedaan kemampuan metakognisi antara siswa yang menulis jurnal belajar dan siswa yang tidak menulis jurnal belajar $(p=0.002)$. Hasil uji hipotesis ditunjukkan dalam Tabel 2.

Tabel 2. Uji Hipotesis Perbedaan Kemampuan Metakognisi

\begin{tabular}{cc}
\hline Keterangan & Nilai \\
\hline Mann-Whitney U & $1,296 \mathrm{E} 3$ \\
Wilcoxon W & $3,248 \mathrm{E} 3$ \\
Z & $-3,134$ \\
P-value & 0,002 \\
\hline
\end{tabular}

Kemampuan metakognisi pada kelas eksperimen meningkat setelah membuat jurnal belajar, apabila dibandingkan dengan kelas kontrol yang tidak ditugaskan menulis jurnal belajar. Hal ini menunjukkan kegiatan menulis jurnal belajar memberikan motivasi kepada siswa untuk mengembangkan kemampuan metakognisinya. Kelas kontrol juga mengalami peningkatan skor metakognisi namun peningkatannya tidak seperti pada kelas eksperimen.

Hasil penelitian ini didukung oleh hasil penelitian yang dilakukan Septiana dkk. [5], yakni sebagian besar siswa kelasyang ditugaskan menulis jurnal belajar dapat berpikir secara metakognitif selama belajar materi sistem imunitas. Hal ini dikarenakan siswa pada kelas yang menulis jurnal belajar selalu merefleksikan kegiatan belajarnya. Kemampuan siswa merefleksikan kegiatan belajar tersebut karena pemanfaatan metakognisi melalui penulisan jurnal belajar. Melalui jurnal belajar siswa dapat memonitor cara berpikirnya saat belajar, maka siswa semakin mampu mengontrol tujuan, motivasi dan perhatian dalam belajar. kegiatan metakognisi berpotensi menghasilkan siswa yang memiliki kompetensi berpikir tingkat tinggi karena memacu motivasi siswa untuk belajar dan meningkatkan hasil belajar. Hal tersebut dikarenakan siswa mampu menyelesaikan tugas belajar dengan baik melalui kemampuan merencanakan, mengatur diri dan mengevaluasi proses belajar yang telah menjadikan siswa memiliki kebermaknaan mendalam terhadap apa yang dipelajari. Strategi metakognisi dapat memonitor kemajuan yang telah dicapai dan digunakan untuk mengontrol aktivitas kognitif serta menjamin tujuan kognitif yang telah dicapai.

Hasil penelitian yang dilakukan oleh Kurniawan dkk. [11] juga mendukung hasil penelitian ini. Hasil penelitian Kurniawan dkk. [11] menunjukkan 66,67\% siswa memperoleh kategori kemampuan metakognisi yang tinggi dan 33,33\% siswa memperoleh kategori kemampuan metakognisi yang cukup. Kemampuan metakognisi siswa dalam pemecahan masalah menggunakan jurnal belajar efektif karena 100\% siswa memperoleh persentase rata-rata kemampuan metakognisi $\geq 66,67 \%$.

Kemampuan metakognisi kelas $\mathrm{X}$ berbeda nyata dengan kemampuan metakognisi kelas XI IPA $(p=0,02)$. Kemampuan metakognisi yang dimiliki oleh siswa kelas X maupun kelas XI termasuk dalam 
kriteria sudah berkembang baik. Kelas XI IPA memiliki kemampuan metakognisi yang lebih tinggi jika dibandingkan dengan kemampuan metakognisi kelas X. menulis jurnal belajar dengan kemampuan metakognisi siswa di SMAN 1 Pringgarata tahun ajaran $2014 / 2015 \quad(p=0,000)$. Hasil uji hipotesis kemampuan menulis jurnal belajar dan kemampuan

Tabel 3. Uji Hipotesis Hubungan Kemampuan Menulis Jurnal Belajar dan Kemampuan Metakognisi

\begin{tabular}{cccc}
\hline & & Jurnal Belajar & Kemampuan Metakognisi \\
\hline Jurnal Belajar & r hitung & 1 & 0,688 \\
& P-value & & 0,000 \\
& r hitung & 0,688 & 1 \\
Kemampuan & P-value & 0,000 & \\
Metakognisi & $\mathrm{N}$ & 62 & 62 \\
& & & \\
\hline
\end{tabular}

Hasil penelitian ini sesuai dengan hasil penelitian yang dilakukan oleh Temur dkk. [12] yang menyatakan bahwa, tingkatan kelas berhubungan dengan kemampuan metakognisi siswa. Desmita [2] mengutip pendapat Flavel yang menyatakan bahwa kemampuan metakognisi siswa akan terus mengalami perkembangan hingga dewasa. Fenomena ini disebabkan siswa semakin menyadari kehendak sadar dari pikirannya sendiri dan orang lain. Temur [12] dan Schunk [13] berpendapat bahwa tingkat perkembangan siswa mempengaruhi metakognisi mereka. Anak yang berusia lebih tua memahami kemampuan mengingat mereka dan batasannya secara lebih baik dibandingkan anak yang lebih muda.

Hasil penelitian lain yang mendukung tidak adanya perbedaan kemampuan metakognisi antara siswa laki-laki dan siswa perempuan adalah hasil penelitian dari Kamid [14]. Hasil penelitian yang dilakukan oleh Kamid [14] pada tahun 2013 menyatakan bahwa kemampuan metakognisi yang digunakan oleh siswa laki-laki dan peremmpuan tidak menunjukkan adanya perbedaan.

Hasil penelitian ini menunjukkan tidak ada perbedaan kemampuan metakognisi siswa laki-laki dan siswa perempuan. Oleh karena itu jenis kelamin bukanlah faktor yang dapat mempengaruhi kemampuan metakognisi. Baik siswa laki-laki maupun siswa perempuan memiliki skor kemampuan metakognisi yang tidak jauh berbeda pada tiap subkemampuan metakognisi. Rata-rata kemampuan metakognisi siswa perempuan dan laki-laki termasuk ke dalam kriteria sudah berkembang baik. Hasil penelitian yang dilakukan oleh Veloo dkk. [15] sesuai dengan hasil penelitian ini, yakni tidak ada perbedaan yang signifikan antara kemampuan metakognisi siswa biologi laki-laki dan siswa biologi perempuan. Siswa laki-laki dan siswa perempuan menggunakan strategi metakognisi yang sama dalam menyelesaikan suatu permasalahan biologi.

\section{Kemampuan Menulis Jurnal Belajar Dan Kemampuan Metakognisi}

Hasil uji hipotesis yang ketiga menunjukkan adanya hubungan yang signifikan antara kemampuan metakognisi disajikan pada Tabel 3.

Hasil uji korelasi ini sesuai dengan hasil penelitian yang dilakukan oleh Graham [6], yang menegaskan dan menganjurkan penulisan jurnal belajar dalam proses pembelajaran. Jurnal belajar interaktif merupakan suatu cara yang digunakan oleh pengajar keperawatan untuk membantu mahasiswa keperawatan dalam mengembangkan kebebasan berpikir, aktivitas berbicara dan berbahasa dari perawat dan akhirnya kesadaran metakognisi mereka. Park [16] juga menyimpulkan bahwa penggunaan jurnal belajar dalam proses pembelajaran merupakan suatu inovasi yang sangat baik, dan hal ini harus dikembangkan kedepannya

\section{KESIMPULAN}

Kesimpulan yang dapat ditarik dari penelitian ini adalah

1. Kemampuan menulis jurnal belajar siswa di SMAN 1 Pringgarata tahun ajaran 2014/2015 meningkat.

2. Kemampuan metakognisi antara siswa pada kelas yang ditugaskan menulis jurnal belajar biologi dengan siswa pada kelas yang tidak ditugaskan menulis jurnal belajar biologi berbeda. Selain itu ada perbedaan kemampuan metakognisi siswa kelas X dengan siswa kelas XI IPA, namun tidak ada perbedaan kemampuan metakognisi siswa perempuan dengan siswa laki-laki.

3. Ada hubungan yang signifikan antara kemampuan menulis jurnal belajar biologi dan kemampuan metakognisi siswa.

\section{DAFTAR PUSTAKA}

[1]. Permendiknas no 22 tahun 2006.

[2]. Desmita. 2014. Psikologi Perkembangan Peserta Didik. Bandung: PT Remaja Rosdakarya.

[3]. Simamora, M., C., Siburian, J., Gardjito. 2014. Analisis Kemampuan Metakognisi Siswa Dalam Pembelajaran Biologi Melalui 
Assesmen Pemecahan Masalah Di Sma Negeri 5 Kota Jambi. (online): http://www.ejmste. com/Makale.aspx?kimlik=2277, diakses tanggal 5 Agustus 2015.

[4]. Paidi. 2011. Pengembangan Perangkat Pembelajaran Biologi Berbasis Masalah. Jurnal Kependidikan. 41, 185-201.

[5]. Septiyana, K., Andreas, P.B.P., dan Wulan, C. 2013. Jurnal Belajar sebagai Strategi Berpikir Metakognitif pada Pembelajaran Imunitas. Unnes Journal of Biology Education. 2, 02-09.

[6]. Graham, B. 1994. Student Journals: A Window to Metacognitive Development. Thesis: University of Lethbridge (Online): https://www.uleth.ca

/dspace/bitstream/handle/10133/1096/Graha m Betty.pdf?, diakses tanggal 22 November 2014.

[7]. Coughlan, A. 2007. Reflective Learning: Keeping A Reflective Learning Journal. $D C U$. Vol. 1:01-07. (Online): https://www.dcu.ie/si tes/default/files/students/Reflectivelearning. pdf, Diakses tanggal 6 Desember 2014.

[8]. Laurens, T. 2011. Pengembangan Metakognisi Dalam Pembelajaran Matematika. (Online); http://p4mriunpat. wordpress.com/2011/11/14/etakognisidalam -pembelajaran diakses tanggal 22 November 2014.

[9]. Hake, R. R. 1999. Analyzing Change/Gain Scores. Dept. of Physics Indiana University. (Online): http://www.physics. indiana.edu diakses tanggal 20 Agustus 2015.
[10]. Jufri, A. W. 2010. Belajar dan Pembelajaran Sains. Mataram: Arga Puji Press.

[11]. Kurniawan, Bambang, H., dan Dwi A. 2010. Efektivitas Penggunaan Jurnal Belajar Dikaji dari Hasil Belajar dan Kemampuan Metakognisi dalam Pembelajaran Matematika. (Online): http:// jurnal.untan.ac.id/index.php/jpdpb/article/vi ew 5837, diakses tanggal 22 November 2014.

[12]. Temur, T., Kargin, T., Bayar, S. A., Bayar, V. 2010. Metacognitive Awareness of Grades 6, 7 and 8 Students in Reading Process. Procedia Social and Behavioral Sciences 2 (2010) 4193-4199.

[13]. Schunk, H. D. 2012. Learning Theories an Educational Perspective. Yogyakarta: Pustaka Pelajar.

[14]. Kamid. 2013. Metakognisi Siswa dalam Menyelesaikan Soal Matematika (Studi Kasus pada Siswa SMP Berdasarkan Gender). Edumatica. 3, 64-67.

[15]. Veloo, A., Rani M., A., dan Hariharan, K. 2014. The Role of Gender in the Use of Metacognitive Awareness Reading Strategies among Biology Students. Asian Social science.Vol. No 1. (Online): http://dx.doi.org/10.55 39/ass.v11n1p67 diakses tanggal 10 Agustus 2015.

[16]. Park, C. 2003. Engaging Students in the Learning Process: the Learning Journal. Journal of Geography in Higher Education. 27,183-199. 